SUULLISET LÄHTEET

Kallimo, K. (2016). Perusturvan toimialajohtaja. Jyväskylän kaupunki. Haastattelu 15.4.2016.

Filander, K. (2017). Karin Filander. Yliopistonlehtori.

Tampereen yliopisto. Haastattelu 3.5.2017.

Heikkinen, A. (2017). Anja Heikkinen. Professori.

Tampereen yliopisto. Haastattelu 24.5.2017.

Järvinen, A. (2017b). Annikki Järvinen. Professori emerita Haastattelu 10.3.2017.

Honka, J. (2017). Juhani Honka. FT. Haastattelu 30.1.2017.

KIRJALLISUUS

Alanen, A. (1983). Elinikäisen kasvatuksen käsite. Teoksessa Alanen A. \& Sihvonen J. (toim.) Elinikäinen kasvatus. Helsinki: Gaudeamus, 14-26.

Alanen, A. (1992). Suomen aikuiskasvatuksen organisaatiomuodot. Opetusmonisteet B 7. Tampere: Tampereen yliopisto.

Filander, K. (2012). Discursive turns from 'Bildung' to managerialism. Memory-work of the Finnish adult education generations. European Journal for Research on the Education and Learning of Adults, RELA 3 (2), 135-153.

Harva, U. (1946). Kansansivistys. Helsinki: Otava. Harva, U. (1958). Aikuiskasvatus. Helsinki: Otava.

Jokinen, J. ( 2017). Tampereen koulukunnan synty ja hajoaminen. Aikuiskasvatuksen tiedeorientaatioita 930-luvulta 2010-Iuvulle. Helsinki: Vapaa sivistystyö VST ry.

Kantasalmi K. \& Nest M. (2014). Johdanto. Valistuksesta elinikäiseen oppimiseen. Teoksessa Kantasalmi, K. \& Nest, M. (toim.). Valistajia, sivistajlia, poliitikkoja ja asiantuntijoita: näkökulmia aikuiskasvatuksen kentän vaikuttajiin. Tampere: Tampere University Press, 233-270.

Karjalainen, E. (1970). Suomen vapaan kansansivistystyön vaiheet. Helsinki: Weilin + Göös.

Paloheimo, H. (1979). Tiedepolitiikan koulukunnat. Politologian tutkimuksen ja sosiologian laitos. N:o 36 Turku: Turun yliopisto.

Peltonen, M. (1969). Oppilasarvostelun häiriöistä. Acta Universitatis Tamperensis ser A 28. Tampere: Tampereen yliopisto.

MUUT

AITURI (2011). Aikuiskasvatuksen tutkimusyhteistyön rakenteelliset innovaatiot. Hanke. https://www. alkuiskasvatuksentutkimusseura fir tutkimus/aituri-hanke-2010-2011/(31.10.2018)
Pantzar, E. (2017). Eero Pantzar. Professori emeritus. Haastattelu 20.5.2017

Poikela, E. (2017). Esa Poikela. Professori emeritus. Haastattelu 21.10.2017.

Suoranta, J. (2017b). Juha Suoranta. Professori. Tampereen yliopisto. Haastattelu 15.8.2017.

Tuomisto, J. (2017). Jukka Tuomisto. Professori emeritus Haastattelu 24.5.2017.

\title{
Päätoimittajat paneelissa
}

Kriittisyys, tieteellisyys ja uteliaisuus ovat arvoja, joihin Aikuiskasvatuksen nykyinen ja tuleva päätoimittaja nojaavat.

Peltonen, M. (1981). Aikuisdidaktiikan perusaineksia. Helsinki: Werner Söderström Oy.

Sihvonen, J. (1996). Sivistystä kaikille vai valituille. Acta Universitatis Tamperensis. ser A vol. 519. Tampere: Tampereen yliopisto.

Suoranta, J. (2006). Aikuiskasvatuksen tieteellistyminen Teoksessa Suoranta J. \& Kauppila J. (toim.). Aikuiskasvatuksen risteysasemalla. Julkaisusarja B. Oppimateriaaleja n:o 23. Joensuu: Joensuu yliopiston täydennyskoulutuskeskus, 21-40.

Tuomisto, J. (1985). Aikuiskasvatuksen kehittymisestã käytäntönä, oppiaineena ja tieteenä. Teoksessa Manni E. \& Tuomisto J. (toim.). Humanistin teemojen tuntumassa. Tampere: Tampereen yliopisto, 171-197.

Tuomisto, J. (2006). Esipuhe. Teoksessa Tuomisto J \& Salo P. (toim.). Edistävä ja viihdyttävä aikuiskasvatus. Tampere: Tampere University Press, 7-11.

Tuomisto, J. (2014). Suunnittelukeskeisen aikuiskoulutuspolitiikan arkkitehdit. Teoksessa Kantasalmi, K. \& Nest, M. (toim.). Valistajia, sivistäjï̈, ikkoja ja asiantuntijoita. Tampere: Tampere ess, 305-340

Vanttaja, M. (1993). Aikuiskasvatuksen tutkimus Suomessa. Aikuiskasvatuksen historian muotoutuminen ja tutkimusten painopisteet vuosin 1970-1990. Pro gradu -tutkielma. Turku: Turun yliopisto.

Wuorenrinne, T. I. \& Kosonen, V. (1949). Zachris Castrén Kansansivistäjä ajatustensa valossa. Helsinki: Otava.
AIKUISKASVATUS ON TIETEENALANSA AINOA VERTAISARVIOITU TIEDELEHTI. MIHIN SITA TARVITAAN?

Heikki Silvennoinen (HS): Koulutuksen ja oppimisen kysymykset kaikkineen ovat muodostuneet entistä tärkeämmäksi tutkimuskohteeksi. Tiedelehti osaltaan pitää alan tutkimusta elinvoimaisena ja tarjoaa kiinnekohdan tutkijoille. Se voi nostaa merkittäviä aiheita yleisempäänkin tietoisuuteen ja keskusteluun.

Ulpukka Isopahkala-Bouret (UI-B): Aikuiskasvatuksen tavoite on olla alansa tutkimuksen edelläkävijä ja edistää tutkimukseen perustuvaa ymmärrystä koulutuksesta, oppimisesta ja kehittämisestä aikuiselämän erilaisissa ympäristöissä. Se mahdollistaa tieteellisen vuoropuheluun, jolloin voi syntyä ymmärrystä yksittäisiä tutkimuksia laajemmista ilmiöistä.

AIKUISKASVATUSTA OPETETAAN JA TUTKITAAN SEITSEMÄSSÄ YLIOPISTOSSA. MILLAINEN SUHDE TIEDELEHDELLÄ ON TIETEENALAAN?

UI-B: Eri yliopistoissa syntyy hieman eri suuntiin haarautuvia määritelmiä aikuiskasvatuksesta. Jos ne saadaan kohtaamaan Aikuiskasvatuksessa, lehdellä on mahdollisuus laajentaa alan toimijoiden itseymmärrystä omasta alasta ja omasta paikasta kentällä.

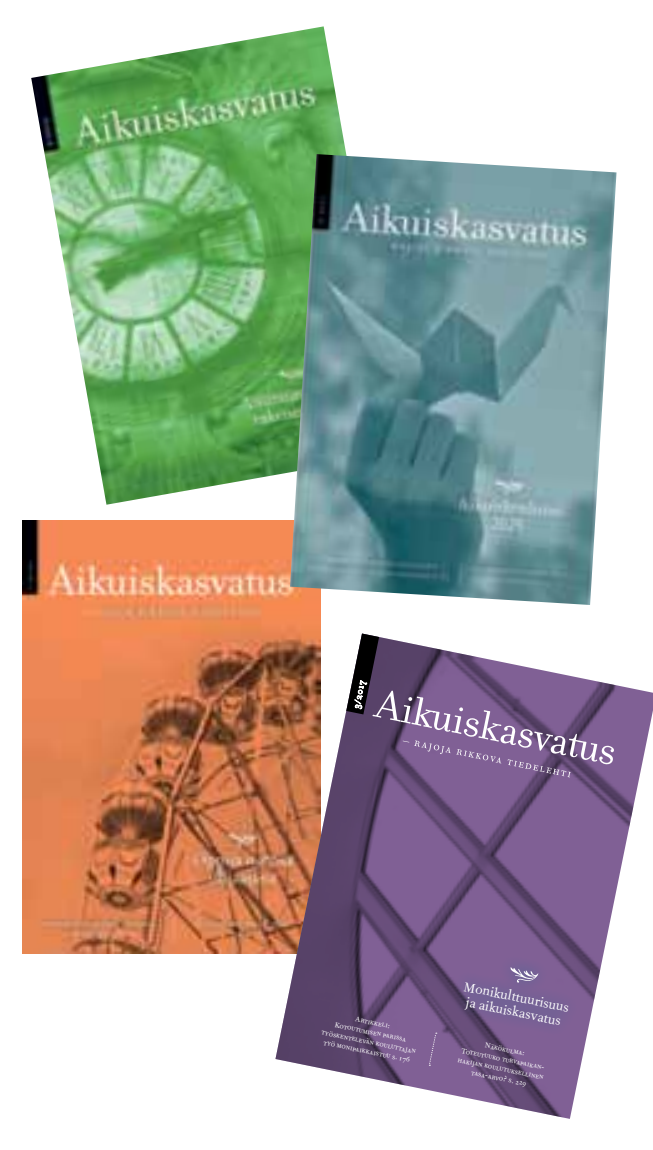

Heikki Silvennoisen päätoimittamia Aikuiskasvatuksen numeroita vuosilta 2010-2018. 


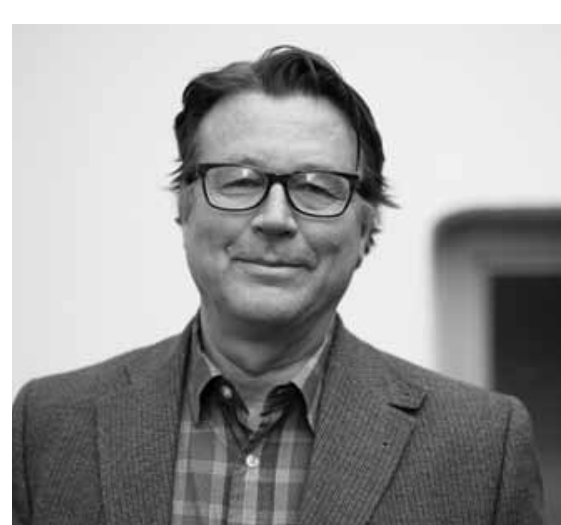

Tieteellisen laadun vaalija

Heikki Silvennoinen on tehnyt Aikuiskasvatusta yhdeksän vuoden ajan mielessään lukija, joka on kiinnostunut yhteiskunnallista asioista ja akuisten elämän muuttumisesta.

$9 \int$ Uskon, että olen onnistunut pitämään ya lehden tieteellistä tasoa ja hyväa suomea. Tiedetekstiltä on perusteltua vaatia sääntöjä noudattavaa, selkeää ja yksiseltt tä kieltä - se on osa tieteellistä kirjoittamista. Yhdeksänvuotiseksi venähtäneen päätoimittajan pestini päättyessä haluan kiittää kaikkia näinä vuosina toimituskunnassa toimineita antoisista keskusteluista kokouksissamme. Olemme kokoontuneet aina rennossa hengessä, vaikka mielipiteiden vaihto on voinut olla kipakkaakin. Erityiskiitoksen ansaitsevat lehden toimituspäälliköt Anneli Kajanto, Annu Griñan, Helka Repo ja Terhi Kouvo. Oli ilo tehdä lehteä kanssanne!"

\section{Heikki Silvennoinen}

- VTT, kasvatustieteen professori (kasvatussosiologia) Turun yliopistossa; koulutussosiologian dosentti Helsingin yliopistossa

- Kirjoitti ensimmäisen artikkelinsa Aikuiskasvatukseen vuonna 1989 yhdessä kollegansa Joel Kivirauman, Turun yliopiston erityispedagogiikan professorin, kanssa koulutuksen ja työvoimapolitiikan kysymyksistä.
HS: On olennaista, että lehdessä käydään alan sisäistä tieteellistä keskustelua koska se vie tutkimusta eteenpäin ja luo tutkijoille edellytyksiä tarjota lehteen sisältöä. Tutkijat ovat lehden sisällöntuottajia. Päätoimittaja vain yrittää parhaansa mukaan luoda tutkijoille houkuttelevat puitteet julkaista lehdessä tutkimuksiaan.

UI-B: Tieteen sisäinen keskustelu ja tutkittavista ilmiöistä käytävä yhteiskunnallinen keskustelu eivät ole toistensa vastakohtia. Lisäämällä tutkittua tietoa voidaan viitoittaa päätöksentekoa ja käytännön työn kehittämistä. Alan ammattilaisille lehti on väline hahmottaa oman toiminnan reunaehtoja.

\section{MISTÄ TUNNISTAA LAADUKKAAN TIEDELEHDEN?}

HS: Tieteellinen laatu on tiedelehden korkein arvo. Ylittääkseen ensimmäisen kynnyksen artikkelikäsikirjoituksen on täytettävä tieteellisyyden kriteerit. Täytyy olla yhteiskunnallisesti tai tieteellisesti merkittävää sanottavaa ja tieteellisesti pätevät välineet argumentoida sanottavansa puolesta. Arvostan tutkimusta, joka koettaa katsoa tutkittavaa ilmiötä uusista näkökulmista ja tuottaa arkiymmärryksen ylittäviä tulkintoja itsestäänselvyyksinä otetuista asioista.

UI-B: Laatu on sidoksissa tiedejulkaisun vaikuttavuuteen. Tutkijat haluavat julkaista tutkimuksiaan arvostetuissa lehdissä, joita luetaan ja joihin viitataan. On tärkeää, että Aikuiskasvatuksella on hyvä maine tieteiden kentällä yli tieteenalarajojen. Tiedejulkaiseminen edellyttää tutkijoita, jotka identifioituvat aikuiskasvatuksen kenttään ja kokevat Aikuiskasvatuksen omaksi julkaisufoorumikseen. Mitä enemmän tutkijat kiinnostuvat alan ilmiöistä, ja kirjoittavat niistä kiinnostavasti, sitä kunnianhimoisemmin lehteä voidaan viedä eteenpäin

\section{MITEN AIKUISKASVATUS-TIEDELEHTI PYSYY} ELINVOIMAISENA?

HS: Tarttumalla rohkeasti, mutta tieteellisyyden kriteereitä noudattaen, suuriin yhteiskunnallisiin kysymyksiin ja globaaleihin teemoihin. Sellaisia ovat esimerkiksi poliittinen osallistuminen ja sen edellyttämä tietämys, kansalaisten ymmärrys valinnoistaan kuluttajina, kulutukseen perustuvan elämäntavan ja kestävän kehityksen yhteydet, informaatiotulva ja tiedon todenperäisyys, kansalaisten aineellisten ja kulttuuristen olojen yhteys koulutussaavutuksiin ja oppimiseen.

1980-luvulta lähtien lehden tieteellinen luonne on vahvistunut ja sisältö laajentunut oppimisesta ja opettamisesta kattamaan aikuisen elämänalueet kokonaisuudessaan. Edeltäjältäni Petri Salolta sain hyvin toimitetun ja monipuolisen lehden.

UI-B: Monitieteisyydellään. Linjauksellaan olla "rajoja rikkova" tiedelehti ja julkaista monitieteistä tutkimusta lehti vastustaa kapeita ja rajoittavia aikuiskasvatuksen määrittelyjä. Elinvoimaisuus edellyttää itsekriittisyyttä ja tarvittaessa kykyä muuttua. Yhtäält on pohdittava, miten lehti pysyy kiinni ajassa ja sen ilmiöissä, toisaalta, millaisia arvoja lehti haluaa edistää ja puolustaa.

Näen aikuiskasvatuksen tasa-arvo- ja oikeudenmukaisuuskysymyksenä: pyrin pitämään lehdessä yllä keskustelua aikuisten yhdenvertaisia mahdollisuuksista, siitä miten aikuisten osallistumisen esteitz̈ voitaisiin purkaa ja rakentaa kaikin puolin avoimempaa, eri taustoista tulevien koulutukseen pääsyä, osallisuutta ja toimijuutta vahvistavaa yhteiskuntaa.

HS: Aikuiskasvatus ei saisi tiedelehtenä ottaa roolia vain kulloinkin vallitsevan koulutuspolitiikan edistäjänä tai esimerkiksi työelämän tarpeiden äänitorvena Julkista koulutuspolitiikkaa ja työelämän vaatimuksia tulee tarkastella kriittisesti, niihin sisältyviä oletuksi kyseenalaistaen ja niiden tarjoamia totuuksia kriittisesti analysoiden.

Aikuiskasvatuksen päätoimittajat 2019-_ Ulpukka Isopahkala-Bouret

2010-2018 Heikki Silvennoinen

2007-2009 Petri Salo

2001-2006 Anja Heikkinen

1998-2000 Reijo Raivola

1992-1997 Kauko Hämäläinen

1981-1991 Jukka Tuomisto

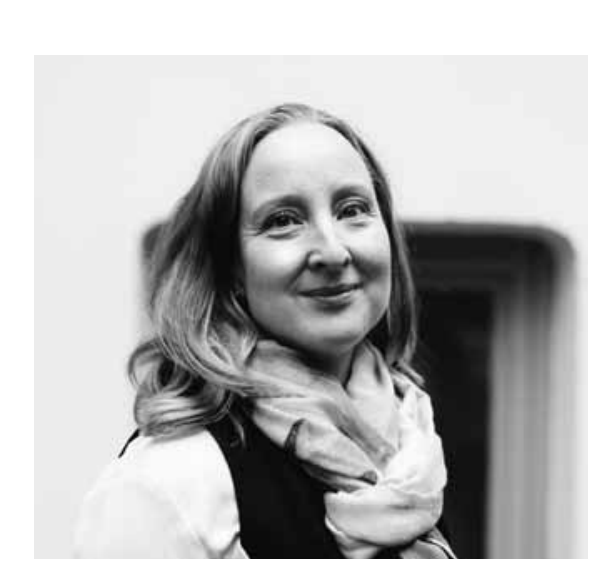

\section{Yhteisön rakentaja}

Ulpukka Isopahkala-Bouret aikoo jatkaa edeltäjänsä avarakatseisella, yhteiskuntaa tarkkanäköisesti luotaavalla linjalla, kun lehti muuttuu avoimeksi verkkojulkaisuksi Journal.fi-alustalle.

$\iint_{\text {tiirtymä avoimeen julkaisemiseen an- }}^{\text {tahdollisuuden kokeilla uudenlai- }}$ sia sisällöntuottamisen tapoja ja tavoitella uusia lukijoita. Yksittäinen juttu voi kiinnostavalla sisällöllään saada aiempaa laajemman levikin kun sisältöjä on helppo jakaa somekanavissa.

Voi olla, että muutoksen myötä on aiempaa vaikeampaa tarkasti määritellä kohderyhmää Kenties lukija ei enää ajattele lehden yksittäistä toimitettua numeroa, vaan sisältö pirstaloituu. Aikuiskasvatuksen kotisivut, blogikirjoitukset ja verkkokeskustelut puolestaan luovat tilaa uudenlaisille yhteisöllisyyden muodoille."

\section{Ulpukka Isopahkala-Boure}

- KT, kasvatustieteen apulaisprofessori (erityisalana koulutuksellinen tasa-arvo ja oikeudenmukaisuus) Turun yliopistossa; aikuiskasvatustieteen dosentti Helsingin yliopistossa

- Kirjoitti Aikuiskasvatukseen ensimmäisen tiedeartikkelinsa vuonna 2008 väitöskirjansa pohjalta asiantuntijuudesta kokemuksena. 